\title{
26. How interactive maps mobilize people in geoactivism
}

\author{
Miren Gutiérrez
}

\begin{abstract}
Thus far little has been said about how maps are employed in activism to unleash sentiments. Employing as a lens the emotional turn currently influencing geography, this article looks at a $15 \mathrm{M}$ map, a cartographic animation that shows a 'connected multitude' of indignad@s as they demonstrated in Spain in 2011; the 'Left-to-die boat' map, tracing the course of a ship in which 63 refugees lost their lives; and the 'Western Africa missing fish' map, which shows foreign fishing vessels operating irregularly in African waters. Interviews, fieldwork, and participatory observation are employed to understand how maps are designed to activate people through emotions. Based on DeSoto (2014) and Muehlenhaus (2013), the chapter also offers a taxonomy as a heuristic tool.
\end{abstract}

Keywords: Emotions; Critical cartography; Data activism; Maps

\section{Emotions in mobilization and maps}

In Poststructuralist Geographies, Doel (1999) challenged readers to envisage a cartography that shimmers and think about ways in which flows, relations, and change can be mapped. Two decades ago, imagining a sparkling map entailed a leap of imagination; today, maps can glitter thanks to the geoweb-combining geographic, geospatial, and geotag overlay systems (Scharl \& Tochtermann, 2007) - and other technologies. The 15M map included in this study is an example. The $15 \mathrm{M}$ or indignad@s movement was a citizen uprising formed in the wake of a sit-down protest on May 15 , 2011 in Madrid to demand a more representative democracy. Figure 26.1 shows an instance of the animated chart, which starts with a few sparkles

Engebretsen, M. and H. Kennedy (eds.), Data Visualization in Society. Amsterdam: Amsterdam University Press, 2020 DOI 10.5117/9789463722902_CH26 




Figure 26.1. A moment in the $15 \mathrm{M}$ map. By Instituto de Biocomputación y Física de Sistemas Complejos, Universidad de Zaragoza. Reprinted with permission.

developing into a landscape of increasingly bright jumping lights indicating interactions - tweets - among the ${ }_{15} \mathrm{M}$ supporters as they joined in. The 15M map is Doel's vision come true.

This chapter is positioned at the juncture between approaches that reckon emotions central in social mobilization (della Porta \& Diani, 2006; Goodwin, Jasper, \& Polletta, 2001, 2004; Melucci, 1996) and the 'emotional turn' in critical cartography, produced by the need to integrate affects in the study of places (Griffin \& Mcquoid, 2012; Maddrell, 2016). On the one hand, there is no protest without strong emotions (Jasper, 1998), which can include 'anger and indignation, fear and disgust, joy, and love' (Goodwin et al., 2001, p. 2). Anger can spur participation, but it cannot sustain it for long. Hope, which Goodwin, Jasper, and Polletta deem 'crucial to sustaining movements', breeds an 'anticipation of improvement' (pp. 19, 66). Namely, mobilization can start with anger, but is sustained by hopefulness. On the other hand, Kennedy and Hill (2017) discuss strong emotional reactions - including 'pleasure, anger, sadness, guilt, shame, relief, worry, love, empathy, excitement, offence'-amongst participants in focus groups exposed to data visualizations. Maps - as particular visualizationscan spur sentiment too (Fabrikant, Christophe, Papastefanou, \& Maggi, 2012; Griffin \& Mcquoid, 2012). In his interview, Panek speaks about how 
making maps can spark strong emotions and feelings of belonging among cartographers.

There is no consensus about what differentiates emotions from other affective states, such as feelings and sentiments (Klettner et al., 2013, p. 66); I am using these terms as synonyms. The focus here is how maps are designed to mobilize people in geoactivism, understood as activism that relies on digital cartography (Gutiérrez, 2018a), not the people being mobilized by charts. Likewise, I make no distinction between 'mobilization', 'action', and 'protest' since these words all indicate 'doing'.

In-depth interviews and empirical observations of relevant cases, as well as participatory observation of one of 'Western Africa's missing fish' maps, which I co-led with colleagues at the Overseas Development Institute (ODI), are employed to observe geoactivist maps. Mapmakers were questioned about how they design maps. The interviewees include Lorenzo Pezzani, researcher at Forensic Oceanography; Juan Carlos Alonso, a designer at Vizzuality (currently at satellitestud.io), which offers cartography for global campaigns on issues such as climate change; Jiri Panek, an expert on emotional mapping; and Daniel Huffman, an independent mapmaker. They have been selected not only for their experience in generating maps with a cause, but also because they are vocal about their strategies as mapmakers. They have given their permission to be named in this article. Empirical observation is employed to contextualize the maps studied here and collect data about the campaigns to which they belong. No causal relationship can be established between these maps and these campaigns' outcomes. The idea instead is to examine how maps are devised to generate reactions, and to determine what elements make them effective. As the lead mapmaker in the 'Western Africa missing fish' project, I employed participant observation to collect data from the processes, meetings, decisions, and internal documents behind the initiative, which are used to enrich this study. The conclusions respond to the initial research question and reflect on the implications of this research for contemporary activism. The main research question in this study is: 'What is it in maps than can make them successfully mobilize people?' A taxonomy of maps is offered at the end of this article as a heuristic tool to create new maps or to examine new cases.

\section{A landscape of emotions}

Some emotions in social movements are shaped by collective action around concrete events and issues, while others can exist in people before they 
connect to campaigning groups (Jasper, 1998, p. 397). The first perspective is employed in this study to establish how cartography is used in advocacy as an instrument of what Muehlenhaus calls 'persuasive geocommunication' (2013). For example, in his interview Alonso talks about how he tries to empower people to act on climate change by using local impact maps to make this global phenomenon more approachable. The 'emotional turn' has influenced cartography to study the links between maps and sentiment from different viewpoints. One is based on the use of technologies to collect and chart emotions spawned by locations (Hauthal \& Burghardt, 2013; Klettner et al., 2013). A second approach focuses on the exploration of the feelings engendered by cartography (Fabrikant et al., 2012; Griffin \& Mcquoid, 2012). Nold (2009) combines both viewpoints. His emotional cartography captures individual biometric data and then explores its emotional implications. This study uses the second approach. Visualizations can present particular standpoints more convincingly than others (Kennedy et al., 2016). As rhetorical artefacts serving someone's interests (Harley, 1989), maps are often fashioned in a way that they can evoke an emotional response and persuade users to believe or do something (Griffin \& Mcquoid, 2012). In his interview, Alonso hypothesizes that maps can situate the observer in remote places by generating vivid emotions connected with places. 'Maps further enhance this recall effect by providing a geographical context that transports the receiver to the place of events', says Alonso. Meanwhile, Huffman explains that when a map is being created with an intent to arouse, this purpose becomes part of its functionality. But what are maps in geoactivism?

\section{A map is a map}

First, geoactivist maps comply with the rules of mapicity, that is, the properties that make a map recognized by users as useful and believable as maps (Denil, 2011). Second, maps can enable people to plan, coordinate, and mobilize. The data infrastructure, information and communication technologies, the geoweb, and other technologies such as data crowdsourcing platforms, satellite data and imagery, sensors and drones, augment the map's capacities. In the hands of activists, as I have written elsewhere, cartography becomes 'action-oriented, participatory, and production tools signifying complex social, political, or technological processes, and mutable interactions and networks for action' (Gutiérrez, 2018a, p. 15). Third, maps are emotion-producing machineries. Kent (2005) focuses on how aesthetic features in cartography can revive memories, while Preston (2008) examines how map symbols can trigger emotional responses. The maps inspected in 


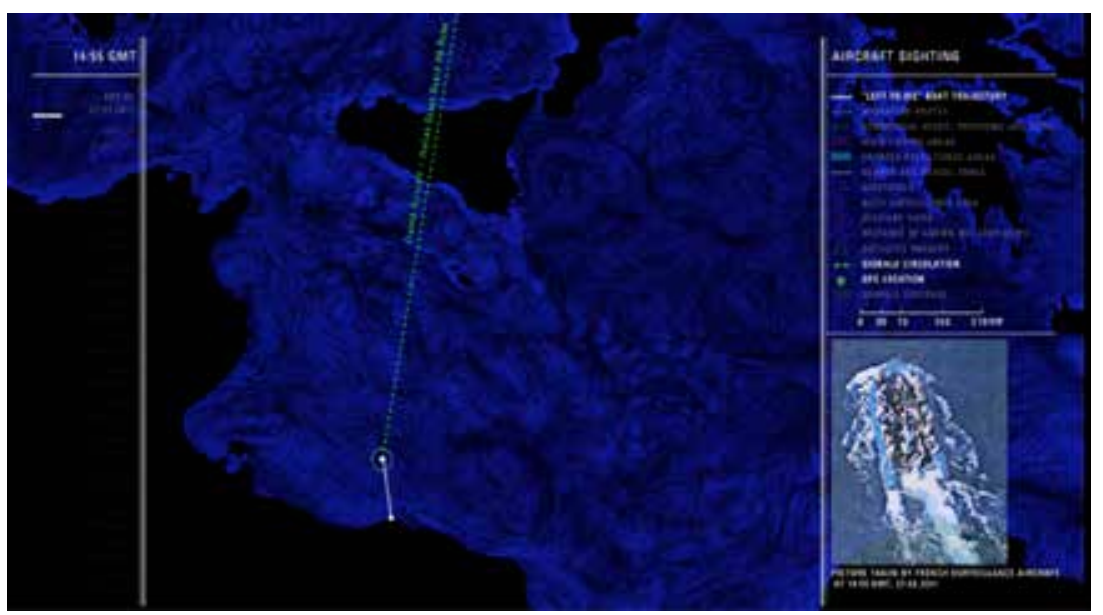

Figure 26.2 A moment of 'Left-to-die boat' map. From Liquid Traces-The Left-to-Die Boat case (https://vimeo.com/89790770). Copyright 2014 by C. Heller \& L. Pezzani. Reprinted with permission.

this study contain impactful elements that are designed to activate reactions. The 'Left-to-die boat' map includes a narrator, videos, and a soundtrack. The 'Western Africa missing fish' map challenges users to detect irregular fishing activity. Meanwhile, the $15 \mathrm{M}$ map evolved in real time, gathering sentiment and pouring it back into the map in the form of light. Figures 26.1, 26.2, and 26.3 show static snapshots of these dynamic maps.

Technologies seem to augment the map's ability to wake up emotions. Van Lammeren et al. conclude in a study comparing $2 \mathrm{D}$ and ${ }_{3} \mathrm{D}$ visualizations that the latter generate stronger affective assessments in people $(2010$, p. 465). Finally, the practice of critical cartography - understood as 'countermapping' (Peluso, 1995) and 'radical cartography' (Denil, 2011)—transforms maps into action. For Doel (1999) and DeSoto (2014), among others, maps are in a constant state of becoming. With the geoweb and other technologies, maps incorporate the dimension of sequential time, sometimes even real time, becoming dynamic (Gutiérrez, 2018b). The properties of digital maps allow civil society organizations to engender 'ways of organising collective life' (Gray, Bounegru, Milan, \& Ciuccarelli, 2016). This is an appropriate idea to understand maps in activism, since social mobilization is never static.

\section{See-think/feel-do}

The maps studied here demand more than just watching or interpretation; they respond to the formula 'see-think-do', coined by Netek and Panek (2016), an awareness-based approach employed to look at crisis mapping. 
I propose a variation, 'see-think/feel-do', since maps can generate meanings and feelings, which jointly shape reactions to the visualizations (Lemke, 2015). Crisis mapping-or the geoactivist practice of charting emergency reports and channelling them to responders on the ground so that they can act (Gutiérrez, 2018a) - deserves closer examination as an example of a 'see-think/feel-do' mechanism. It cannot occur without convincing mapmakers (deployers), enthusiastic witnesses (reporters), and cooperating humanitarian workers: the three communities that converge around the map (Gutiérrez, 2018a). The challenge in mapping citizen data does not derive from its technical complexity, but from the summoning power of the map and the mapmakers' capacity to sustain the effort. An example is Ushahidi, a visualization tool that is widely employed in mapping humanitarian emergencies. Hundreds of Ushahidi deployments have flopped due to the lack of crowds transmitting reports (Vota, 2012). Fatigue is an issue in Ushahidi deployments as some volunteering mapmakers can exhaust themselves in the effort to help disaster victims (Gutiérrez, 2018a).

This study is focused on how activist maps that comply with the rules of mapicity are devised to generate emotions and ultimately mobilize. The next section considers three examples.

\section{Three geoactivist maps}

\section{The 'Left-to-die boat' map}

On March 27, 2011, a group of 72 people were forced by armed Libyan soldiers on-board an inflatable craft, which headed in the direction of the island of Lampedusa (BBC, 2012). Only nine would survive. The 'Left-to-die boat' map shows that the failure to save them was due to callousness, since satellite imagery and data, testimonies, and other evidence substantiate that their dire situation had been detected and ignored. What made this case different from that of the 1,50o people who died attempting to cross the Mediterranean in 2011 was that the boat's calls 'would appear to have been ignored by a range of fishing vessels, a military helicopter and a large naval vessel' (Committee on Migration, Refugees and Displaced Persons, 2012). The people on the boat launched distress signals transmitting their location, and sustained repeated interactions with others (Heller \& Pezzani, 2014). As part of its operations in Libya, an arms embargo was enforced in the Mediterranean Sea, making the area 'the most highly surveilled section of the sea in the 
entire world' (Heller \& Pezzani, 2014). The map illustrates how other ships come across the boat's path but never pause to try a rescue. However, the Convention on the Law of the Sea calls for ships to 'render assistance to any person found at sea in danger of being lost' (United Nations, 1994, p. 6o). Figure 26.2 is a static snapshot of the online version of the map.

The map was crafted by Forensic Oceanography, a team based within the Forensic Architecture agency, which specializes in techniques to scrutinize deaths and human rights abuses (Forensic Architecture, 2016). It employs a charged visual, textual, and acoustic language. It darkens when night falls, and lightens when the sun rises, making the journey realistic. Looking at emotional response to map design, Fabrikant et al. conclude the maps that use 'semantically correct colour assignments', for example blue for water, receive better responses (2012, p. 3). The ominous twirling cobalt shades that surround the Left-to-die boat signify a threat too. The animation is accompanied by the voice of a narrator, who uses loaded terms to recount the trip. The people on-board were escaping 'violent repression' in Libya and, without food, water, or fuel, ended up 'chained to the seas' open expanse', the narrator claims. The map shows that other ships in the boat's vicinity did not respond to its calls; the storyteller says that the refugees were 'denied minimal assistance' (Heller \& Pezzani, 2014). A timeline induces a sense of urgency as the account proceeds. The soundtrack-a recording by the Laboratory of Applied Bioacoustics (Listening to the Deep Ocean Environment, 2017) — feels like a threatening marine roar. Consistent with Edsall's explorations of the use of music to convey the emotional context of geospatial data (2011), the ocean's thunder employed by the 'Left-to-die boat' map suits the grim facts as they unfold.

In his interview, Pezzani, who made the map, explains these formal elements were the result of a search for an adequate language 'to engage with the migrant crisis', an attempt to offer a different view than the conventional 'spectacle' of migrants as either invaders or victims. He adds: 'We did not want to risk being unwillingly complicit with the border regime.' The idea was to cast 'a disobedient gaze over this situation' because the migrant crisis is also a 'visual struggle', yet there is a lack of certain images'. The migrants encountered several ships, and these engagements were photographed by both sides, but the pictures have been kept secret, he recounts, as the survivors were stripped of their belongings. Every detail is carefully orchestrated in this map, but this is done without sentimentalism, as the pivotal element of the project is the map and the data. The complete meaning of the map is begot by the interrelation of the signs and words working together. The map arouses emotions partly in response to the mapmaker's 'new approach to 
mapping', paraphrasing Field and Demaj (2012, p. 73). 'Distress is probably one of the most fitting reactions' to the map, argues Pezzani.

The map supported a report to the European Parliamentary Assembly, which concludes that 'too many persons have lost their lives in circumstances similar to the 63 persons on board the "left-to-die boat"' (Committee on Migration, Refugees and Displaced Persons, 2012). This report includes only one image: that of the 'Left-to-die boat' map (p. 23). A coalition of organizations led a series of legal actions in the national courts of each of the states participating in the military operations against Libya (Pezzani \& Heller, 2011). Should these states fail to investigate the incident, a case may be brought to the European Court of Human Rights, says Pezzani.

\section{The 'Western Africa missing fish' map}

Western Africa has some of the world's most abundant fishery resources, which are under threat from illegal or irregular fishing, which puts at risk the food security of millions of people. An industrialized fleet is catching too many fish, and much of the activity falls into irregular fishing, which is difficult to deter. The interactive 'Western Africa missing fish' map used by the ODI provides comprehensive visual evidence, for the first time, about foreign fleets engaging in irregular operations in developing countries.

The static snapshot in Figure 26.3 is based on the interactive 'Western Africa missing fish' map, which tracks 35 fish cargo vessels for a year. Figure 26.3 visualizes Automatic Identification System (AIS) signals emitted by one of these vessels, Sierra Loba, from 6 to 23 August 2013, as the ship operates in Senegal's waters. Vessels of a certain size must regularly launch AIS signals to avoid a collision. Fish cargo vessels such as Sierra Loba are specialized in gathering, processing, and deep-freezing fish for transportation. The zigzagging movements in Figure 26.3 are typical of a cargo ship in search of fishing vessels willing to empty their holds (Daniels et al., 2016, p. 18). The snapshot of the map in Figure 26.3 exposes the boat searching and stopping to transfer fish, an operation that is marked by the red circles indicating that the vessel is stationary for a number of hours (p. 18). However, Senegal forbids fish transfers in its waters as it lacks the resources to monitor whether fish caught illegally are involved in the operation.

The map and its accompanying report are unadorned, as they display no human suffering, but it unleashed a wave of disapproval. News media coverage played a key role. The project had been designed by my colleagues and I as a full-blown data activist endeavour, complete with a media outreach 


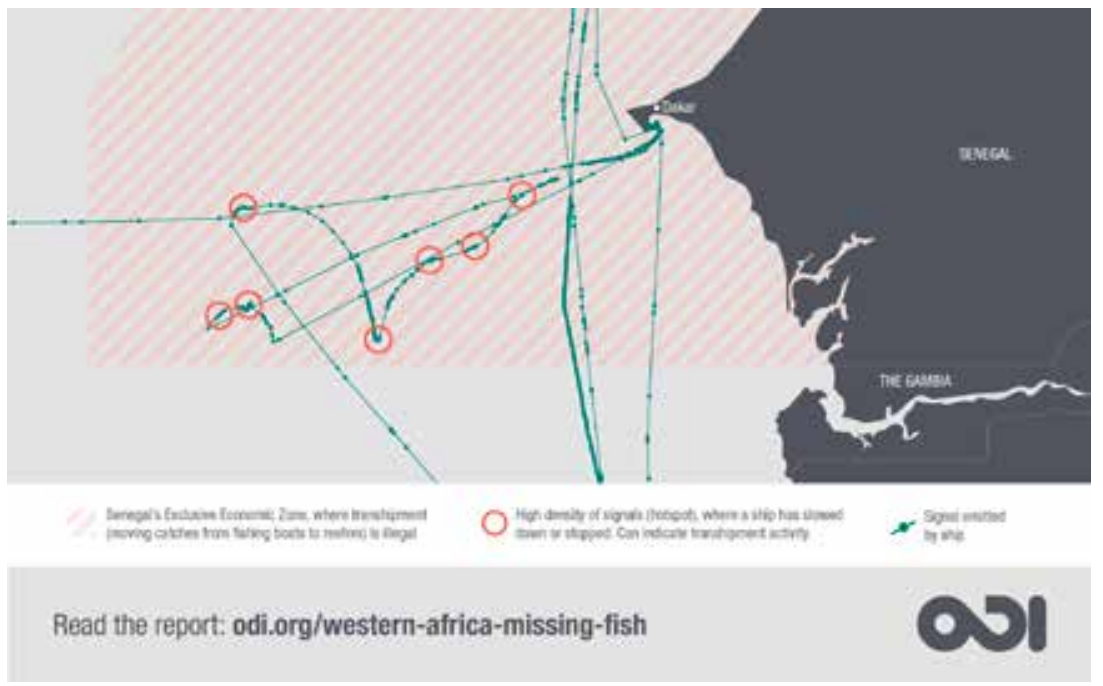

Figure 26.3. Sierra Loba, as it engages in irregular operations in Senegalese coastal waters. From 'Western Africa's missing fish: The impacts of illegal, unreported and unregulated fishing and under-reporting catches by foreign fleets', by A. Daniels, M. Gutiérrez, G. Fanjul, A. Guereña, I. Matheson, \& K. Watkins, 2016 (https://www.odi.org/publications/10459-western-africas-missingfish-impacts-illegal-unreported-and-unregulated-fishing-and-under-reporting). Copyright 2016 by Overseas Development Institute. Reprinted with permission.

plan. As a result, more than 150 media outlets from 35 countries had covered the story in several languages only weeks after its publication. Headlines including 'Illegal fishing "killing" livelihoods across in West Africa' (Bahati, 2016), 'UE, accomplice in the pillaging of African waters' (Caballero, 2016) and 'To end the looting of African waters' (Jarrett, 2017) stressed the loss that illegal fishing means for Africa. ${ }^{1}$ These stories included poignant words such as 'pillage', 'looting', 'fight', 'killing', 'starving', and 'plundering'. That is, the loaded language was not offered by the map, but by the interpretations it triggered within the different news media. Journalistic coverage was especially intense in Western Africa; dozens of local media outlets in Congo, Morocco, Ghana, South Africa, Mauritania, Nigeria, Burkina Faso, Senegal, Ivory Coast, and Guinea picked up the news, which is not usual with ODI reports. Right after the publication of the map in June 2016, Guinea banned all international fishing activities in its waters, referring to the ODI investigation as the trigger for this decision (BBC, 2016). Consequently, Guinea was removed from the list of non-cooperative countries in the fight against illegal fishing (Karuri, 2016). The report accompanying the map

$1 \quad$ Orginal titles are 'La Unión Europea, cómplice del saqueo de los mares africanos' and 'Pour en finir avec le pillage des eaux africaines'. All translations by the author. 
endorsed the implementation of the Food and Agriculture Organization's Agreement on Port State Measures to Prevent, Deter and Eliminate Illegal Fishing, which was concluded in 2009 but had not entered into force for lack of signatories. It became operational only in June 2016, coinciding with the launch of the map. After a seven-year hiatus, the treaty quickly gained traction and more countries joined in. As of July 2016, only a month after the launch, it had 34 state parties (from the initial 25 a month earlier). There were other aftershocks. For example, the government of South Korea-the country of origin of some of the cargo vessels exposed by the map-contacted ODI to proclaim that they were cleaning up their act. The 'Western Africa's missing fish' map was the first published study on illegal fishing behaviour using data visualizations. Since 2016, new maps have been produced using the same approaches. Although these events cannot be directly attributed to it, the map and associated report seemed to have generated a wave of annoyance that put illegal fishing in Africa on the table.

\section{The $15 \mathrm{M}$ map}

The 15M map is one in a series that guided the indignad@s movement in Spain. DeSoto (2014) notes they incorporate network visualizations, conceptual maps, alert systems, databases, and georeferenced wikis at a scale never seen before 2011, illustrating 'the art of cartography by connected multitudes'. The map in Figure 26.1, made by Instituto de Biocomputación y Física de Sistemas Complejos, Universidad de Zaragoza, stands out among the series because of its resemblance to Doel's simmering map. However, all the ${ }_{15} \mathrm{M}$ charts are central to a broader tekné that allowed a great number of 'brains and bodies' to connect through time, space, emotion, and behaviour (DeSoto, 2014, p. 360). DeSoto classifies the $15 \mathrm{M}$ maps into two groups: diagnostic 'discomforting maps', responding to an initial phase of indignation, and performative 'empowering maps', conducive to action. ${ }^{2}$ Figure 26.1 - an empowering map-shows the contagious 'emotional climate' of 'joy' that powered the indignad@s protests (p. 359).

Are the three maps equality stimulating? The maps included in this chapter share some commonalities, but they are basically different. To understand what makes them effective, next they are appraised based on DeSoto's dual taxonomy (discomforting/empowering) and Muehlenhaus's classification of persuasive geocommunication. The idea is to produce a taxonomy that can serve as a heuristic tool for further analysis. 


\section{Taxonomy}

Muehlenhaus divides maps into four categories depending on the amount of data they assimilate and whether they are 'rationalist' or 'emotive' (2013). Maps can employ an 'authoritative style', which is data rich and magisterial looking; an 'understated style', relying on small datasets and minimalist presentations; a 'propagandist style', data-light and 'rhetorical in nature'; and a 'sensationalist style', resorting to rich datasets and making heavy use of rhetorical styling' (Muehlenhaus, 2013, pp. 6-10). Although Muehlenhaus acknowledges that this classification may not include all varieties, it is a useful tool to examine geoactivist maps. Table 26.1 combines DeSoto's and Muehlenhaus's classifications.

Table 26.1 Three maps seen from DeSoto's and Muehlenhaus's categorizations

\begin{tabular}{llll}
\hline & 'Left-to-die boat' & 'Western Africa missing fish' & 15M map \\
\hline Objective & Discomforting & Discomforting & Empowering \\
Data volume & Rich & Rich & Rich \\
Appearance & Partly rationalist/ & Mostly rationalist/slightly & Slightly rationalist/ \\
& partly emotive & emotive & mostly emotive \\
\hline
\end{tabular}

Note. Elaboration by the author based on Muehlenhaus (2013) and DeSoto (2014).

These maps differ in the type of emotions that they were designed to trigger. By denouncing a wrong, the 'Western Africa missing fish' and the 'Left-to-die boat' maps generate distress; they are discomforting maps. Meanwhile, the $15 \mathrm{M}$ is an empowering map, which feeds and grows on enthusiasm.

Maps can integrate massive amounts of data without incorporating different types of data. Therefore, the origins of the data are critical to determining data richness in maps. The 'Left-to-die boat' visualizes public data from satellite AIS data providers, heat signatures, radar signals, and data from other surveillance technologies recording the movement of nearby ships (Heller \& Pezzani, 2014). It also counts on the testimonies from the survivors, a soundtrack and music, and other content. The mixture of types of data makes it complex when it integrates filmed interviews, sounds mimicking what had happened on-board, and a narrator's voice from the perspective of the people on the boat. The 'Western Africa missing fish' map assimilates dynamic AIS data with a static database which describes each vessel, including physical information (e.g. length, carrying capacity), as well as information on its owners, operators, and registries. As with the previous example, this case not only includes massive amounts of data but 
also different data sources. Meanwhile, the ${ }_{15} \mathrm{M}$ map shows big amounts of data, without the richness in variety displayed by the other two. In this animated chart, there are two basic data layers: geographic data and the timestamped data of the tweets and retweets. The difference is that this map evolves in quasi-real-time, producing an 'alternative, community-owned definition of a territory' (Dosemagen, Warren, \& Wylie, 2011), which makes it complex. Namely, these maps are not characterized by their paucity of data; nor are they propagandistic (Muehlenhaus, 2013).

The 'Western Africa missing fish' chart is an example of 'authoritative' geocommunication, as paraphrasing Muehlenhaus (2013, p. 6), attempts to persuade by looking legitimate to make the spectator infer that scientific rigour is being observed. The 'Left-to-die boat' map shows a style halfway between authoritative and sensationalist; it can be said to include 'a variety of tricks to excite and engage map users' (p. 10). The narrator's voice in pseudo real-time, the sound of the threatening sea, the timeline, and the testimonials provide a charged atmosphere. However, the amount of data, as well as their variety, bestows the map a sense of reliability. The ${ }_{15} \mathrm{M}$ map is more sensationalist than authoritative, but while it shows none of the data complexity of the other two, it cannot be said to be data poor. The dancing lights that weave the map's landscape, superimposed on a dark blue emphasizing them, are bursting with liveliness. The map does not look scientific or formal, but animated and exciting.

\section{Discussion and conclusion}

What is it in maps than can make them mobilize people in activism? The interviews and geoactivist maps observed in this study suggest that striking a balance between emotive elements and rich data, in terms of both quantity and complexity, is crucial. From the less emotive to the most emotive, these maps use expressive language too. The three of them generated strong reactions according to the 'see-think/feel-do' formula. Although it cannot be inferred from this exercise that all data-rich geoactivist maps that are rationalist or emotive in adequate proportions will be effective, these are characteristics found in three successful cases of maps which either mobilized people or sustained action. These samples illustrate how maps play a role in stimulating the two basic emotions that influence people to 'do' things: negative, motivating feelings during an early stage of the mobilization, and hope to sustain it. 


\section{References}

Bahati, L. (2016, July 1). Illegal fishing 'killing' livelihoods across in West Africa. AllAfrica News. Retrieved from http://www.africanews.com/2016/o7/o1/ illegal-fishing-in-western-africa/

BBC. (2012, October 28). The left to die boat. BBC. Retrieved from http://www.bbc. co.uk/programmes/poio1r27

BBC. (2016, June 30). Africa highlights: Guinea bans foreign fishing. BBC. Retrieved from http://www.bbc.com/news/live/world-africa-36452771

Caballero, C. (2016, July 5). La Unión Europea, cómplice del saqueo de los mares africanos. El País. Retrieved from https://elpais.com/elpais/2016/o7/o4/planeta_futuro/1467647004_67089o.html

Committee on Migration, Refugees and Displaced Persons. (2012). Lives lost in the Mediterranean Sea: Who is responsible?' Parliamentary Assembly, Council of Europe. Retrieved September 12, 2018 from https://assembly.coe.int/CommitteeDocs/2012/20120329_mig_RPT.EN.pdf

Daniels, A., Gutiérrez, M., Fanjul, G., Guereña, A., Matheson, I., \& Watkins, K. (2016). Western Africa's missing fish. London: Overseas Development Institute. Retrieved July 1, 2018 from https://www.odi.org/sites/odi.org.uk/files/resourcedocuments/10665.pdf

della Porta, D., \& Diani, M. (2006). Social movements: An introduction (2nd ed.). Malden, Oxford, \& Victoria: Blackwell Publishing.

Denil, M. (2011). The search for a radical cartography. Cartographic Perspectives, 68. Retrieved August 1, 2018 from http://cartographicperspectives.org/index. $\mathrm{php} /$ journal/article/view/cp68-denil/14

DeSoto, P. (2014). Los mapas del \#15M: El arte de La cartografía multitud conectada'. Universitat Oberta de Catalunya, 25.

Doel, M. (1999). Poststructualist geographies: The diabolical art of spatial science. Edinburgh: University of Edinburgh Press.

Dosemagen, S., Warren, J., \& Wylie, S. (2011). Grassroots mapping: Creating a participatory map-making process centered on discourse. Journal of Aesthetics and Protest (8). Retrieved August 16, 2018 from https://www.joaap.org/issue8/ GrassrootsMapping.htm

Edsall, R. (2011). 'Sounds dangerous: Emotion, geovisual analytics, and music'. Kartographische Nachrichten, 62(6), 291-299.

Fabrikant, S. I., Christophe, S., Papastefanou, G., \& Maggi, S. (2012). Emotional response to map design aesthetics. GIScience. Retrieved September 12, 2018 from http://www.zora.uzh.ch/71701/1/2012_FabrikantS_giscience2012_paper_64.pdf 
Field, K., \& Demaj, D. (2012). Reasserting design relevance in cartography: Some concepts. The Cartographic Journal, 49(1), 70-76. https://doi.org/10.1179/00087 04112Z.00000000011

Forensic Architecture. (2016, November 29). Left-to-die boat. Retrieved November 29, 2018 from http://www.forensic-architecture.org/case/left-die-boat/

Goodwin, J., Jasper, J. M., \& Polletta, F. (Eds.). (2001). Passionate politics: Emotions and social movements. Chicago: University of Chicago Press.

Goodwin, J., Jasper, J. M., \& Polletta, F. (2004). Emotional dimensions of social movements. In: D. A. Snow, S. A. Soule, \& H. Kriesi (Eds.), The Blackwell companion to social movements. (pp. 413-432). Malden, Oxford, \& Carlton: Wiley-Blackwell.

Gray, J., Bounegru, L., Milan, S., \& Ciuccarelli, P. (2016). Ways of seeing data: Toward a critical literacy for data visualizations as research objects and research devices. In: S. Kubitschko \& A. Kaun (Eds.), Innovative methods in media and communication research. (pp. 290-325). Cham: Palgrave Macmillan.

Griffin, A., \& Mcquoid, J. (2012). At the intersection of maps and emotion: The challenge of spatially representing experience. Kartographische Nachrichten 62(6), 291-99.

Gutiérrez, M. (2018a). Data activism and social change. London: Palgrave Pivot.

Gutiérrez, M. (2018b). Maputopias: cartographies of communication, coordination and action - the cases of Ushahidi and InfoAmazonia. GeoJournal, 1-20. https:// doi.org/10.1007/s10708-018-9853-8

Harley, J. B. (1989). Deconstructing the map. Cartographica: The International Journal for Geographic Information and Geovisualization 26(2), 1-20. https://doi. org/10.3138/E635-7827-1757-9T53

Hauthal, E., \& Burghardt, D. (2013). Detection, analysis and visualisation of georeferenced emotions. In: M. F. Buchroithner (Ed.). Proceedings of the 26 th International Cartographic Conference, August 25-30, 2013, Dresden, Germany. https://icaci. org/files/documents/ICC_proceedings/ICC2013/ICC2013_Proceedings.pdf

Heller, C., \& Pezzani, L. (2014). Liquid traces —The Left-to-die boat case [Video file]. Retrieved July 1, 2018 from https://vimeo.com/89790770

Jarrett, M. B. (2017, May 5). Pour en finir avec le pillage des eaux africaines. Le Monde Afrique. Retrieved from http://www.lemonde.fr/afrique/article/2017/05/05/ pour-en-finir-avec-le-pillage-des-eaux-africaines_5123210_3212.html

Jasper, J. M. (1998). The emotions of protest: Affective and reactive emotions in and around social movements. Sociological Forum, 13(3), 397-424.

Karuri, K. (2016, October 12). Guinea removed from list of countries not cooperating with eliminating illegal fishing. Africa News. Retrieved from http:// www.africanews.com/2016/10/12/guinea-removed-from-list-of-countries-notcooperating-with-eliminating-illegal/ 
Kennedy, H., \& Hill, R. L. (2017). The feeling of numbers: Emotions in everyday engagements with data and their visualisation. Sociology, 52(4), 830-848. https:// doi.org/10.1177/0038038516674675

Kent, A.J. (2005). Aesthetics: A lost cause in cartographic theory?' The Cartographic Journal, 42(2), 182-188. https://doi.org/10.1179/000870405X61487

Klettner, S., Huang, H., Schmidt, M., \& Gartner, G. (2013). Crowdsourcing affective responses to space. Kartographische Nachrichten, 2(3), 66-72.

Lemke, J. (2015). Feeling and meaning: A unitary bio-semiotic account. In: P. P. Trifonas (Ed.), International handbook of semiotics. (pp. 589-616). New York \& London: Springer.

Listening to the Deep Ocean Environment. (2017). Presentation. Retrieved November 29, 2018 from http://www.listentothedeep.com/acoustics/index2. php?web=presentation\&lang=en

Maddrell, A. (2016). Mapping grief: A conceptual framework for understanding the spatial dimensions of bereavement, mourning and remembrance. Social \& Cultural Geography, 17(2), 166-88. https://doi.org/10.1080/14649365.2015.1075579

Melucci, A. (1996). The playing self. Cambridge: Cambridge University Press.

Muehlenhaus, I. (2013). Four rhetorical styles of persuasive geocommunication: An initial taxonomy. Dresden: International Cartographic Association. Retrieved August 1, 2018 from https://icaci.org/files/documents/ICC_proceedings/ ICC2013/_extendedAbstract/355_proceeding.pdf

Netek, A., \& Panek, J. (2016, July). Framework See-Think-Do as a Tool for Crowdsourcing Support. Paper presented at the XXIII ISPRS Congress. http://doi.org/10.5194/ isprsarchives-XLI-B6-13-2016

Nold, C. (Ed.) (2009). Emotional cartography: Technologies of the self. Retrieved August 15, 2018 from http://www.emotionalcartography.net/

Peluso, N. L. (1995). Whose woods are these? Territories in Kalimantan'. Antipode, 27(4), 383-406. https://doi.org/10.1111/j.1467-8330.1995.tboo286.x

Pezzani, L., \& Heller, C. (2011). Case: 'Left-to-die boat'. Retrieved July 1, 2018 from https://www.fidh.org/IMG/pdf/fo-report.pdf

Preston, D. (2008). Off the map: An exploration of emotive cartography, power and place. In: E. Tilley (Ed.), Power \& place: Refereed proceedings of the Australian \& New Zealand Communication Association Conference.

Scharl, A., \& Tochtermann, K. (Eds.). (2007). The geospatial web: How geobrowsers, social software and the web 2.0 are shaping the network society. London: Springer-Verlag.

United Nations. (1994). Convention on the law of the sea. Retrieved July 28, 2018 from http://www.un.org/depts/los/convention_agreements/texts/unclos/ unclos_e.pdf 
van Lammeren, R., Houtkamp, J. M., Colijn, S., Hilferink, M., \& Bouwman, A. (2010). Affective appraisal of $3 \mathrm{D}$ land use visualization. Computers, Environment and Urban Systems, 34(6), 465-475. https://doi.org/10.1016/j.compenvurbsys.2010.07.001 Vota, W. (2012, August 29). CrowdGlobe: The dead Ushahidi reality behind 12,795 Ushahidi crowdmaps. ICTworks. Retrieved from http://www.ictworks. org/2012/o8/29/crowdglobe-dead-ushahidi-reality-behind-12795-crowdmaps/

\section{About the author}

Miren Gutiérrez's interests are on data activism, or how data infrastructure can be utilized for social change in development, climate change, and environmental issues. She is a researcher at the University of Deusto, and a Research Associate at Overseas Development Institute, London, and at Datactive, University of Amsterdam. She holds a PhD in Communication Sciences. 